\title{
The Littoral Diatoms of the Liverpool and Port Erin Shores.
}

\author{
By
}

F. M. Ghazzawi, B.Sc.,

Cairo, and Department of Oceanography, Liverpool University.

\section{Contents.}

\begin{tabular}{|c|c|c|c|c|c|c|c|c|c|c|}
\hline Introduction & . & . & . & . & . & . & . & . & . & \\
\hline General Ecology . & . & . & . & . & . & . & . & . & . & . \\
\hline Methods of Collection & . & . & . & . & . & . & . & . & . & . \\
\hline Fixing and Clearing & . & . & . & . & . & . & . & . & . & . \\
\hline Mounting . . & . & . & . & . & . & . & . & . & . & . \\
\hline General Remarks & . & . & . & . & . & . & . & . & . & . \\
\hline Classification . & . & & . & . & . & . & . & . & . & . \\
\hline Species Identified & . & & & . & . & . & . & . & . & . \\
\hline List of Abbreviations & . & & . & . & . & . & . & . & . & . \\
\hline Notes on Species & . & & . & . & . & . & . & . & . & . \\
\hline Acknowledgments & . & & . & . & . & . & . & . & . & . \\
\hline List of Literature & . & . & . & . & . & . & . & . & . & . \\
\hline
\end{tabular}

\section{INTRODUCTION.}

Certain diatoms seem to live predominantly on the foreshore. While the pelagic diatoms have received very much study, relatively little attention has been given to the shore forms. There is no satisfactory account of these organisms as they occur on the coasts of Lancashire and Isle of Man, and one may expect that they have much importance as the food of many animals. In a further paper I will deal with this question. For this reason I deal here only with those littoral diatoms found along the Mersey Beach, in the vicinity of Liverpool, and with those collected from the sandy and rocky shore of Port Erin (Isle of Man). Masses of these organisms can easily be recognised with the naked eye, discolouration of the sand and mud being due mainly to them, together with some species of desmids and dinoflagellates.

On a sandy beach like that of Port Erin, it appears as if the diatoms attain maxima of abundance during the spring and summer. They do not totally disappear from those localities during the cold months, though they become relatively scarce. During the very cold months of winter I have found diatoms on the rather muddy beach of part of the Mersey 
Estuary known as the "Dingle." Apparently there are optimum conditions of sunlight and temperature for the growth and multiplication of these organisms.

\section{General Ecology.}

In their living state, littoral diatoms are seen to be attached to the coarse surface of the sand grains. A minute sand grain under the microscope seems to be a substratum for not less than 20 or 30 diatoms, of various genera and species. They may also be seen gliding between the sand grains. It is in these littoral forms that the free motion of diatoms is easily recognisable. This movement is sometimes said to be due entirely to the protoplasmic action of the part of the coleoderm in the position of the raphe. It is relatively considerable, for a minute naviculoid diatom $(20 \mu)$ is able to strike an obstacle in its way, that is far larger than itself, with such force as to push it aside! A naviculoid diatom seems to move along the side of the frustule where the median line-or raphe-extends, for when this boat-like Navicula is turned on its side by just pressing delicately with a needle on the cover slip, it turns over again immediately and proceeds to move as before. The motion is more particularly noticed in those littoral diatoms which are almost free. In particular, it is in those forms that have a true conspicuous raphe, that the free motion in diatoms is best seen. In Surirella gemma, for example, where the raphe is less defined the motion is languid though still perceptible. The movement is a sort of backward and forward one, but it can also be a vertical or oblique one in response to the light. Phototropism is indeed marked among these forms, for on leaving the diatoms with sand in a fairly shallow enamel dish, surrounded (or even not) by a black paper, the organisms are found after a short time to be seeking the surface of the sand, so that they form, in due time, a thick yellowish green or brown layer, obviously in response to the incident light: this is the result of their motion. Most of the diatoms found on the shore exist in the free state, particularly those possessing a true raphe, but in addition, many are found connected by their valve surfaces in filaments, such as Melosira nummuloides and Acnanthes longipes, which are attached to other Algæ by more or less long stipes. Others again, such as Schizonema, are enclosed in gelatinous tubes.

\section{Methods of Collection.}

It has been suggested, as one of the best methods (8), that pieces of wellwashed cotton cloth, of the size of a pocket-handkerchief, should be laid on the sand surface, when they will pick up, by their fibres, the diatoms, excluding the sand grains. This, however, proved to be of no use at all, since it was found that a great number of diatoms are left behind and are 
not attached to the cloth, while large amounts of small particles of sand are always picked up. Scraping the sand surface is by far the best way. The sand, with the diatoms, is placed in a fairly wide shallow glass dish, all the outside of which is covered with black paper. The sample of mud is then covered with water (taken from the shore where they were collected) to the height of, say, half an inch. This is then left for at least six hours, when practically all the diatoms form a thick yellowish green coating on the sand surface. It has been stated that the diatoms will be found floating in the layer of water above the sand surface, from which they can be pipetted or siphoned, but this is not the case, for the shore diatoms show a vigorous tendency to remain attached to the surface of sand grains and do not float in the water. Therefore, the best method I have found is to give the dish a slight gentle rotatory motion, when part of the diatoms float up in this water. I filter this, re-scrape the layer of diatoms from the sand surface, and filter this again through Number 16 to 20 bolting silk. This silk is sand-proof, to a sandy beach like that of Port Erin. It allows practically all the diatoms to pass through the silk as an intense yellowish green filtrate. If minute thread-like organic impurities pass through they can be easily got rid of during treatment with acids, and even these do not interfere with the diatoms mounted on a slip as do the objectionable sand grains. This silk filter even allows certain true planktonic species, thrown down by the tide from the open sea, to pass through. Thus in my filtrate such species as Coscinodiscus radiatus, $C$. excentricus, Actinoptychus undulatus, and Biddulphia aurita, were found. This filtration method is by far the best I have tried, and it is recommended to anyone for collecting and cleaning shore diatoms.

For studying them in the living state, the diatoms are kept in either their natural water or in Miquel solution sea-water (modified by Allen and Nelson, 1). Before treatment with acids, for the purpose of studying the frustules, it is necessary to centrifuge them and thus get rid of the bulk of the water.

\section{Fixing and Clearing.}

Gran and Angst (5) state that " for the determination of the species, $95 \%$ alcohol or $4 \%$ formaldehyde in sea-water is a sufficient preservative. A solution made of 5 c.c. of $40 \%$ formaldehyde, 5 c.c. glacial acetic acid, 40 c.c. sea-water and diluted to 100 c.c. by the addition of water containing diatoms, serves for cytological studies." It is not, however, sufficient to study the diatoms when alive, though that would help in the identification of species to a certain extent, and it is necessary to see the diatom shells, depleted of their delicate organic cell-contents, so as to render the striation clear and distinct. It is always necessary to centrifuge the diatoms. They are then treated with a corrosive material. For this purpose 
I have used fuming nitric acid to the extent of 1-2 c.c. to every $\frac{1}{2}$ c.c. of centrifuged diatoms, and have boiled the mixture for a few seconds until the red-brown fumes of acid disappear. To this liquid distilled water is added to fill the test-tube and the mixture is cooled. A white precipitate is found in the course of an hour. The liquid is drained off and the precipitate washed repeatedly with distilled water until there is no trace of acid. The above operation takes from one to two hours, when one is left with perfect clean frustules ready for examination. The diatoms have to be mounted dry. To dehydrate the frustules, a few drops of the acidfree precipitate are taken up in a pipette and spread over a clean slide or cover slip, which is then put in an electric oven (temp. $100^{\circ} \mathrm{C}$.), when all the water evaporates completely in a few minutes, and the diatom skeletons are left dry and ready for mounting.

\section{Mounting.}

The diatoms have to be mounted in a suitable medium. The visibility of markings such as the striation of diatoms is proportional to the difference between the refractive indices of the object and the medium in which it is mounted. The refractive index of the diatom silex is about $1 \cdot 43$, hence the diatom is not seen in concentrated sulphuric acid, as this has nearly the same refractive index. Canada balsam $(n=1 \cdot 54)$, monobromide of naphthaline $(n=1 \cdot 658)$, and styrax are among the media that have higher refractive indices than that of silex. I find Canada balsam and styrax unsuitable owing to their low coefficient of visibility. Monobromide of naphthaline is a liquid and is therefore unsuitable. A good mounting medium is a simple one that I have come across by mere chance and I think it is stable. A slide was found in the Liverpool Oceanography Laboratory, and on examination I found it to contain Gyrosigma balticum, Pleurosigma angulatum, and Surirella gemma, all mounted in a yellowish solid medium. On the slide is written "Piperine and antimony bromide," obviously indicating that this is the mounting medium. The striations of both Pleurosigma and Surirella are clear and distinct in every detail even under the $\frac{1}{8}$-inch high-power objective. It is also very astonishing that, though the mounting was dated March 22nd, 1891, it is still as perfect as if it had been prepared to-day, despite its forty years of age, a fact which is evidence of the stability of the medium. This then must be a very good medium of high refractive index, which is not recorded in any of the references to Diatomaceæ in the Journal of the Royal Microscopical Society from 1860. I was supplied with both piperine and antimony bromide, and with the help of Dr. Daniel, I started to utilise it, with, I believe, considerable success.

Piperine is an inexpensive alkaloid of the formula $\mathrm{C}_{17} \mathrm{H}_{14} \mathrm{NO}_{3}$. It is 
almost insoluble in water. It is only a very weak base and on hydrolysis gives piperidine and piperic acid. It can be obtained in a very pure state as straw-coloured crystals, with a melting point of $128^{\circ} \mathrm{C} .\left(262 \cdot 4^{\circ} \mathrm{F}\right.$.). When it is melted it dissolves the tribromide of antimony very freely. Piperine, if heated alone directly on a bunsen flame, melts quickly into a colourless liquid which chars (blackens) with continued heat. All this may take place in the course of one minute. Bromide of antimony $\left(\mathrm{Sb} \mathrm{Br}_{3}\right)$ melts at a lower temperature and also into a transparent liquid. Both solidify again immediately they are removed from the source of heat. In their liquid state while still hot, if they are allowed to mix, an orange or yellowish colour is produced, the intensity of the colour being dependent upon the proportion of both substances. Piperine must be used in excess of the bromide of antimony, for if the latter is in excess it crystallises out on cooling, with the result that a turbid, useless medium is formed. Different proportions of piperine and antimony bromide have been prepared and sent to the Geological Department here to find out the refractive indices. Unfortunately, I have been informed that they were unable to find these, as the medium is insoluble in their oils. It seems, however, from the examination of the various slides prepared with this mounting medium in different proportions that the best proportion is 2 parts of piperine : 1 part of $\mathrm{Sb} \mathrm{Br}_{3}$. Here the diatoms with their striation are so very distinct and clear that nothing more in this direction can be desired. Two parts by weight of piperine are taken with one part by weight of antimony bromide, and both are finely ground together in a mortar in their solid state, when a yellow colour immediately develops. I do not know whether this yellow material is a new chemical compound, or not. A small portion of this solid medium is put on a slide, or a cover slip, with dry diatoms. The slide or cover slip is now put on a hot plate the temperature of which must not greatly exceed $128^{\circ} \mathrm{C}$. (which is the melting-point of piperine). Under no circumstances should this medium be heated directly on the flame. As soon as the mounting medium melts completely either lower a cover glass, or a slip, on it and take it away immediately from the source of heat, when it solidifies. A $\frac{1}{8}$-inch high-power objective gives highly satisfactory results, and the 1/12th (oil immersion) objective still better results, the striation being distinct in every detail, particularly in Pleurosigmæ which are exceedingly delicate and fine.

\section{General Remarks.}

The diatoms recorded in this paper are true littoral forms, but among them the reader will notice certain species as Coscinodiscus, Actinoptychus, Biddulphia and the like, which are true pelagic forms. The writer believes that such forms are thrown out on the shore by the rising tide, 
and left there. The shore seems to be an unfavourable medium for their life, for in no instance were any of these forms found alive. The littoral diatoms here recorded include those living freely on the sand or mud, as well as those found attached to Algæ, rocks, shells, and other supports. The latter diatoms are particularly the filamentous forms. It seems also that there are no specific Algæ or water plants that are most favourable for particular diatoms; some of the filamentous forms even attach themselves to other diatoms. They are found healthy, and of different species attached to red, brown, and green Algæ.

Three main spots have been examined, namely, the "Jetty" (Pier Head, Liverpool), "Dingle shore" along the Merseyside, and the sandy beach of Port Erin (Isle of Man). It is curious to find a few freshwater forms living along the shore of the River Mersey where the water is brackish, but still covered periodically by flood tides. It seems as if the diatoms of the shore can stand water of different salinities. Common forms-particularly the Nitzschiates and some filamentous forms-are found both along the brackish Merseyside and on the highly saline beach of Port Erin. It may be the light-which is important in the process of assimilation - that is the main factor controlling the abundance of shore diatoms. It may be that these organisms get their food substances from the water that covers them at high tide, but I think it probable that drainage from the land, to the shore, is the condition that matters most. So there is still much to be done by comparing other beaches, where there is very much less land drainage carrying resolved sewage constituents, with the Dingle and Port Erin Bay.

\section{CLASSIFICATION.}

The classification adopted here is based on those of West and Fritsch (1927), and Lebour (1930).

\section{DIATOMALES or BACILLARIALES.}

Centric $\approx$

Discoides

Families Coscinodiscaceæ

Melosiraceæ.

Solenoidae

Family Rhizosoleniaceæ.

Biddulphioida

Family Biddulphiaceæ. 


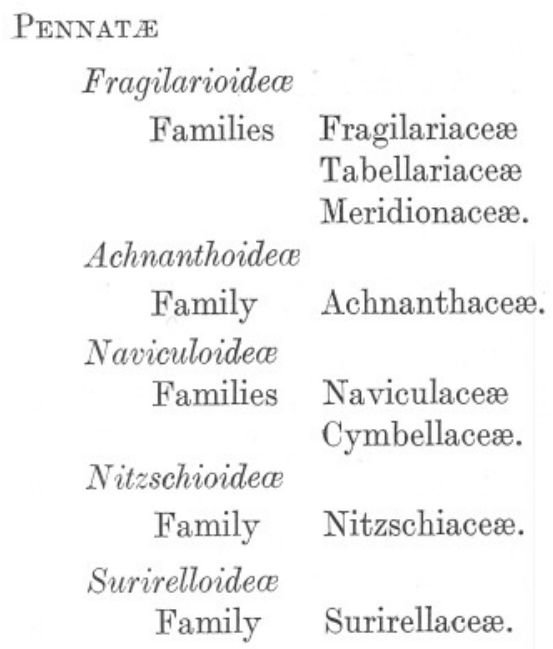

List of SPECIES IDENTIFIED.

\section{Group Centricæ.}

Family Coscinodiscacea.

Genus Coscinodiscus.

1. Coscinodiscus excentricus Ehr. Dingle, Port Erin, rare.

2. C. lineatus Ehr. Dingle, rare.

3. C. nitidus Greg. Port Erin, rare.

4. C. radiatus Ehr. Dingle, Port Erin, rare.

Genus Actinoptychus.

1. Actinoptychus undulatus (Bailey). Dingle, Port Erin, rare.

Family Melosiracece.

Genus Melosira.

1. Melosira sulcata (Ehr.).

Orthothira marina W. Sm. Dingle shore, rare.

2. M. nummuloides (Lyngb.). Dingle shore, Jetty, Port Erin, abundant. Family Rhizosoleniacea.

Genus Rhizosolenia.

1. Rhizosolenia Shrubsolii Cleve. Dingle, very rare.

Family Biddulphiacea.

Genus Biddulphia.

1. Biddulphia aurita (Lyngb.). Port Erin, few.

2. B. granulata Roper. Dingle, rare.

3. B. rhombus (Ehr.). Dingle, rare. 
Genus Attheya.

1. Attheya decora West (?). Port Erin, very scarce.

\section{Group Pennatæ.}

Family Fragilariacea.

Genus Fragilaria.

1. Fragilaria oceanica Cleve. Jetty (Pier Head), rare.

2. F. striatula Lyngb. Jetty, few.

Genus Synedra.

1. Synedra affinis Kutz. Dingle, Port Erin, abundant.

2. S. tabulata (Ag.). Dingle, abundant.

3. S. suberpa Kutz. Port Erin, abundant.

4. S. gracitis Kutz. Dingle, abundant.

Family Tabellariacea.

Genus Rhabdonema.

1. Rhabdonema arcuatum (Lyngb.). Port Erin, abundant.

2. R. minutum Kutz. Dingle, abundant.

Genus Grammatophora.

1. Grammatophora marina (Lyngb.). Port Erin, abundant.

2. G. serpentina W. Sm. Port Erin, abundant.

3. G. islandica Ehr. Port Erin, Dingle, rare.

4. G. angulosa Ehr. Port Erin, Dingle, common.

Family Meridionacea.

Genus Licmophora.

1. Licmophora flabellata Ag. Port Erin, abundant.

2. L. juergensii Ag. Dingle, few. Port Erin, abundant.

3. L. gracilis (Ehr.). Port Erin, abundant.

4. L. dalmatica (Kutz.). Port Erin, abundant.

5. L. lyngbyei (Kutz.). Port Erin, abundant.

Family Achnanthesacece.

Genus Achnanthes.

1. Achnanthes longipes Ag. Port Erin, abundant.

2. A. brevipes Ag. Dingle Shore, Port Erin, abundant.

3. A. subsessilis Kutz. Dingle, Port Erin, common.

Genus Cocconeis.

1. Cocconeis placentula Ehr. Port Erin, abundant.

2. C. scutellum Ehr. Dingle, Port Erin, few.

3. C. dirputa Greg. Port Erin, very rare. 
Family Cymbellacece.

Genus Amphora.

1. Amphora complexa Greg. Port Erin, abundant.

2. A. coffceiformis (Ag.). Port Erin, abundant.

3. A. cymbifera Greg. Dingle, not common.

4. A. lavis Greg. Port Erin, common.

5. A. pellucida Greg. Port Erin, common.

6. A. pusilla Greg. Dingle, Port Erin, rare.

Family Naviculacece.

Genus Caloneis.

1. Caloneis liber (W. Sm.). Dingle, Port Erin, common.

2. C. cemula (A. Schmidt). Port Erin, few.

Genus Diploneis.

1. Diploneis smithii (Breb.). Port Erin, abundant.

2. D. elliptica (Kutz.). Port Erin, Dingle, few.

3. D. litoralis (Donkin). Port Erin, common.

Genus Navicula.

1. Navicula crucigera (W. Sm.). Dingle, abundant.

2. N. tumida W. Sm. Dingle, few.

3. N. grevillei (Ag.). Dingle, abundant.

4. N. bottnica Grun. Dingle, rare.

5. N. pusilla W. Sm. Dingle, Port Erin, common.

6. N. punctulata W. Sm. Dingle, common.

7. N. lyra Ehr. Port Erin, rare.

8. N. humerosa Breb. Port Erin, Dingle, very abundant.

9. N. pygmcea Kutz. Port Erin, fairly abundant.

10. N.tumens W. Sm. Dingle, abundant.

11. N. distans (W. Sm.). Dingle, common.

Genus Gyrosigma.

1. Gyrosigma attenuatum (Kutz.). Dingle, abundant.

2. G. hippocampus (Ehr.). Dingle, Jetty, fairly common.

3. G. balticum (Ehr.). Dingle, Jetty, common.

4. G. spencerii (Quekett). Dingle, not common.

5. G. distortum (W. Sm.). Dingle, abundant.

6. G. fasciola (Ehr.). Dingle, common.

Genus Pleurosigma.

1. Pleurosigma obscurum W. Sm. Port Erin, rare. Dingle, common.

2. P. angulatum (Quekett). Dingle, common. 
3. P. angulatum quadratum (W. Sm.). Dingle, very abundant in summer.

4. P. nubecula W. Sm. Port Erin, few.

Genus Amphiprora.

1. Amphiprora paludosa W. Sm. Port Erin, common.

2. A. plicata Greg. Port Erin, few.

Genus Tropidoneis.

1. Tropidoneis maxima (Greg.). Port Erin, common.

2. T. pusilla (Greg.). Port Erin, common.

Genus Amphipleura.

1. Amphipleura pellucida Kutz. Jetty, rare.

2. A. sigmoidea W. Sm. Jetty, rare.

3. A. rutilans (Trent). Dingle, Port Erin, abundant.

Family Nitzschiacea.

Genus Nitzschia.

1. Nitzschia panduriformis Greg. Dingle, not common.

2. N. bilobata W. Sm. Port Erin shore, abundant.

3. N. vivax W. Sm. Port Erin, abundant.

4. N. spathulata Breb. Port Erin, common.

5. N. angularis W. Sm. Dingle, common.

6. N. closterium W. Sm. Dingle, Port Erin, common.

7. N. reversa W. Sm. Dingle, Port Erin, rare.

8. N. acicularis (Kutz.). Dingle, abundant.

9. N. linearis (Ag.). Jetty, Dingle, not common.

10. N. sigma (Kutz.). Port Erin, very rare.

11. N. valida Cleve \& Grun. Dingle, rare.

12. N. tania W. Sm. Dingle, Port Erin, common.

13. N. parvula W. Sm. Jetty, very rare.

14. N. sigmoidea W. Sm. Dingle, few.

15. N. litoralis Grun. Port Erin, not common.

Genus Hantzschia.

1. Hantzschia virgata (Roper). Port Erin, common.

2. N. amphioxys (Ehr.). Dingle, rare.

Family Surirellacea.

Genus Surirella.

1. Surirella gemma Ehr. Dingle, very abundant in summer.

2. S. ovata Kutz. Jetty, Dingle, rare.

3. S. lata W. Sm. Dingle, very rare. 
List of Abbreviations.

$\begin{array}{ll}\text { Ag. } & =\text { C. A. Agardh. } \\ \text { Breb. } & =\text { De Brebisson. } \\ \text { Ehr. } & =\text { D. C. G. Ehrenberg. } \\ \text { Hass. } & =\text { A. H. Hassall. } \\ \text { Kutz. } & =\text { F. T. Kutzing. } \\ \text { Lyngb. } & =\text { H. C. Lyngbye. } \\ \text { W. Sm. } & =\text { W. Smith. } \\ \text { Thw. } & =\text { G. H. K. Thwaites. } \\ \text { Greg. } & =\text { W. Gregory. }\end{array}$

Notes on Species.

The species of Coscinodiscus were never found alive on the shore. Melosira nummuloides seems to be a true littoral form, and was always healthy, had living chloroplasts and was reproducing, while $M$. sulcata was never found alive. The species Attheya decora West resembles that described by Boyer, except that the figure he gives is different from the actual specimens I examined, in that two spines are directed to opposite directions and the others are nearly straight. The length of each spine is half that of the frustule. The length of the valve is $30 \mu$ in one species and $14 \mu$ in another with varying breadth. Synedra affinis Kutz and Licmophora flabellata Ag. were attached to other green Algæ and even to other diatoms, particularly those enclosed in gelatinous tubes (Schizonema). Rhabdonema arcuatum (Lyngb.) was scraped from molluscan shells. The Licmophora species live more or less together among other flora on the rocky shore and not on the sands. It seems that such stipitate, as well as other filamentous forms, prefer a rocky substratum, perhaps on account of its stability; the sand grains being subject to the tidal movements. Moreover, such forms find, in the vicinity of rocks, small areas of water left behind by the tide. Such small ditches of water seem to be indispensable for the life of these diatoms, unlike the free forms, such as Navicula, which can live attached to sand grains, which are only covered by tidal water twice every twenty-four hours, but which nevertheless are able to continue living under these conditions.

\section{ACKNOWLEDGMENTS.}

I am indebted to the late Professor Johnstone for his valuable aid and advice, to Dr. Daniel for his continued interest and help in this work, to Mr. J. H. Fraser for his kind assistance, and to the Mersey Docks and Harbour Board for permission to work on the beach. 


\section{LIST OF LITERATURE.}

1. Allen, E. J., and Nelson, E. W. 1910. On the Artificial Culture of Marine Plankton Organisms. Jour. Mar. Biol. Assoc., N.S., Vol. VIII, No. 5.

2. Boyer, P. S. 1900. The Biddulphioid Forms of North American Diatomaceæ. Proc. Acad. Nat. Sc. Philadelphia, L.

3. - 1926, 1927. Synopsis of the North American Diatomaceæ. Parts I and II, Ibid., LXXVIII, LXXIX, Supp.

4. Cleve, P. T., and Grunow, A. 1880. Beitrage zur Kenntniss der Arktischen Diatomeen. K. Svensk. Vet-Ak. Handl., XVII, No. 2.

5. Gran, H. H., and Angst, E. C. 1930. Plankton Diatoms of Puget Sound. Pub. Puget Sound Biol. Stat., Vol. 7.

6. Gregory, W. 1857. On New Forms of Marine Diatomaceæ found in the Firth of Clyde and in Loch Fyne. Trans. Roy. Soc., Edin., XXI, Edinburgh.

7. Karsten, G. 1898. Die Diatomeen der Kieler Bucht. Wiss. Meeres. Abt. Kiel, IV, Kiel.

8. Kendall, O. 1915. Methods of collecting Diatoms from Surface of Mud. Journ. Roy. Micr. Soc., 1915.

9. Lebour, M. V. 1930. The Planktonic Diatoms of Northern Seas Ray Society.

10. Sмттн, W. 1853, 1856. A Synopsis of the British Diatomaceæ. Vols. I and II.

11. West, G. S., and Fritsch, F. E. 1927. A Treatise on the British Freshwater Algæ. 